\title{
Evaluasi Sistem Pengendalian Intern Penerimaan Kas Pada Pdam Tirta Anoa Kota Kendari
}

\author{
Oleh \\ Andi Basru Wawo ${ }^{1}$, Fitriaman ${ }^{2}$, Syadam Malik ${ }^{3}$ \\ Email : syadamlalemba@gmail.com
}

\begin{abstract}
This research aims to evaluate the suitability of internal control of cash receipts at the PDAM Tirta Anoa in the city of kendari. Data collection methods in this research are interviews and documentation. This research uses descriptive analysis that explains the evaluation of the internal control system.

The results of the research show that strenght of the internal control system of cash receipts at the PDAM Tirta Anoa in the city of kendari is the existence of password authorization in the operation of SIPDAM and training for employees. However, it also has a weakness in the internal control system of cash receipts to the city where the city of kendari, such as document storage has not been handled properly, and when electricity is off all transactions are stopped as well. In general, the internal control system of cash receipts at the PDAM Tirta Anoa in the city of kendari is good enough, although it has several weakness.

The conclusion of this research is.internal control system also has adequate cash enough receipts and operating effectively viewed from the insur-suppotring elements in the internal control of cash receipts.
\end{abstract}

Keywords: internal control system, cash receipts

\section{PENDAHULUAN}

Perusahaan Daerah Air Minum (PDAM) merupakan perusahaan Badan Usaha Milik Daerah (BUMD). Perusahaan Daerah Air Minum (PDAM) merupakan salah satu unit usaha milik daerah, yang bergerak dalam distribusi air bersih, untuk meningkatkan kesejahteraan masyarakat yang mencakup aspek sosial, kesehatan dan umum. Pengendalian internal kas merupakan prosedur-prosedur secara terperinci yang dipakai oleh pimpinan pengelola untuk mengawasi atau mengendalikan usaha kolektif. Pengendalian dapat diartikan sebagai alat untuk mengkoordinasi aktivitas perusahaan agar sesuai dengan rencana semula. Pengendalian internal yang baik dan efektif sangat diperlukan untuk melindungi harta perusahaan khususnya kas. Salah satu cara untuk melakukan pengendalian internal adalah dengan menyusun sistem pengendalian internal yang memadai.

Aset yang paling likuid pada perusahaan adalah kas. Dilihat dari sifatnya kas merupakan aset yang paling lancar dan hampir setiap transaksi perusahaan selalu mempengaruhi kas. Kas merupakan komponen penting dalam kelancaran jalannya kegiatan operasional perusahaan. Karena sifatnya yang likuid, maka kas mudah digelapkan sehingga diperlukan pengendalian intern terhadap kas dengan memisahkan fungsi-fungsi penyimpanan, pelaksanaan dan pencatatan. Tanpa adanya pengendalian intern terhadap kas, maka akan mudah terjadinya penggelapan kas (Agoes, 2012). 
Pengendalian intern yang dirancang dengan baik terhadap struktur organisasi yang di dalamnya terdapat pembagian tanggungjawab fungsional kepada unit-unit organisasi yang dibentuk untuk melaksanakan kegiatan-kegiatan pokok perusahaan, seperti pemisahan fungsi operasional, fungsi penyimpanan dan fungsi pencatatan. Penting bagi suatu perusahaan menerapkan pengendalian intern sebagai penunjang dalam menjalankan usahanya. Hal tersebut disesuaikan dengan keadaan dan kondisi masing-masing perusahaan karena jenis dan kondisi perusahaan yang berbeda beda (Mulyadi, 2008).

Penerimaan kas pada PDAM Tirta Anoa Kota Kendari berasal dari tagihan rekening air dan pemasangan sambungan rekening baru. Penerimaan kas dari tagihan air merupakan penerimaan yang diperoleh perusahaan yang berasal dari pelunasan piutang dari penjualan air kepada pelanggan. Sedangkan penerimaan kas dari pemasangan sambungan rekening baru merupakan penerimaan kas yang berasal dari pemasangan sambungan pipa baru oleh pelanggan baru.

Terlihat bahwa pada aktivitas penerimaan kas dari PDAM Tirta Anoa Kota Kendari belum sepenuhnya terdapat pemisahan tugas. Karena petugas yang bertanggungjawab menangani kas dan menyimpan kas merangkap sebagai petugas pencatat transaksi kas.

Berdasarkan uraian latar belakang diatas, maka permasalahan pokok yang dapat dirumuskan dalam penelitian ini adalah Apakah sistem pengendalian intern penerimaan kas pada PADAM Tirta Anoa telah memadai? Tujuan penelitian ini adalah untuk mengetahui kesesuaian pengendalian intern penerimaan kas pada PDAM Tirta Anoa Kota Kendari

\section{KAJIAN PUSTAKA}

\section{Pengertian Evaluasi}

Kata evaluasi berasal dari bahasa Inggris evaluation yang berarti penilaian atau penaksiran (Echols dan Shadily, 2007). Sedangkan menurut Stufflebeam yang dikutip oleh Wirawan (2011), mendefinisikan evaluasi sebagai suatu proses menggambarkan, memperoleh, dan menyajikan informasi yang berguna untuk merumuskan suatu alternatif keputusan. Menurut definisi ini, maka istilah evaluasi itu mengandung pengertian suatu tindakan atau suatu proses untuk menentukan nilai dari sesuatu. Dari beberapa pengertian di atas dapat disimpulkan bahwa evaluasi merupakan sebuah cara, tindakan atau proses untuk memperoleh informasi yang dapat digunakan dalam menentukan suatu keputusan.

\section{Pengertian Sistem dan Prosedur}

Romney dan Steinbart (2012:2) mendefinisikan sistem adalah rangkaian dua atau lebih komponen-komponen yang saling berhubungan, yang berinteraksi untuk mencapai suatu tujuan. Definisi prosedur menurut Mulyadi (2001:5) adalah suatu urutan kegiatan klerikal, biasanya melibatkan beberapa orang dalam satu departemen atau lebih, yang dibuat untuk menjamin penanganan secara seragam transaksi perusahaan yang terjadi berulang-ulang.

Menurut "Hall (2012 :5) sistem merupakan komponen yang saling berkaitan (Interelated) atau subsistem -subsistem yang bersatu untuk mencapai tujuan yang sama (common purpose)". Menurut "Mulyadi (2010 :5) sistem merupakan suatu jaringan yang dibuat menurut pola yang terpadu untuk melaksanakan kegiatan pokok perusahaan". Sedangkan menurut "Marron (2010:1) sistem merupakan jaringan dari prosedur-prosedur yang disusun dalam rangkaian secara menyeluruh unutk melaksanakan berbagai kegiatan atau fungsi pokok dalam suatu badan usaha.

Berdasarkan beberapa pendapat yang dikemukakan diatas dapat ditarik kesimpulan bahwa sistem adalah kumpulan bagian-bagian atau sub sistem-sub sistem yang disatukan dan dirancang untuk mencapai suatu tujuan. 


\section{Pengertian Pengendalian Internal}

Mulyadi (2010), mendefinisikan pengendalian internal meliputi struktur organisasi, metode dan ukuran-ukuran yang dikoordinasikan untuk menjaga kekayaan organisasi, mengecek ketelitian dan keandalan data-data akuntansi, meningkatkan efisiensi dan efektivitas operasi, dan mendorong dipatuhinya kebijakan-kebijakan manajemen yang telah ditetapkan.

\section{Komponen Pengendalian Internal}

Pengendalian intern terdiri atas lima komponen yang saling terkait berikut ini (Agoes, 2012):

1. lingkungan pengendalian

2. penaksiran risiko

3. aktivitas pengendalian

4. informasi dan komunikasi

5. pemantauan

\section{Tujuan Pengendalian Internal}

Adapun tujuan pengendalian intern menurut Arens (2013) adalah sebagai berikut:

1. Keandalan laporan keuangan

2. Efisiensi dan efektifitas kegiatan operasi

3. Kepatuhan terhadap hukum dan peraturan

\section{Unsur-Unsur Pengendalian Internal}

Menurut Mulyadi (2010), unsur-unsur pokok sistem pengendalian intern adalah sebagai berikut: (1) Struktur organisasi yang memisahkan tanggungjawab fungsional secara tegas. (2)Sistem wewenang dan prosedur pencatatan yang memberikan perlindungan yang cukup terhadap kekayaan, utang, pendapatan dan biaya. (3) praktek yang sehat (4) karyawan yang mutunya sesuai tanggung jawab

\section{Pemahaman dan Evaluasi atas Pengendalian Internal}

Agoes (2012) mengemukakan bahwa: Auditor harus mendokumentasikan pemahamannya tentang komponen pengendalian intern entitas yang diperoleh untuk merencanakan audit. Bentuk dan isi dokumentasi dipengaruhi oleh ukuran dan kompleksitas entitas, serta sifat pengendalian intern entitas.

\section{Keterbatasan Pengendalian Internal}

Faktor lain yang membatasi pengendalian adalah biaya pengendalian intern entitas tidak boleh melebihi manfaat yang diharapkan dari pengendalian tersebut. Meskipun hubungan manfaat biaya merupakan kriteria utama yang harus dipertimbangkan dalam pendesainan pengendalian intern, pengukuran secara tepat biaya dan manfaat umumnya tidak mungkin dilakukan. Oleh karena itu, manajemen melakukan estimasi kualitatif dan kuantitatif serta pertimbangan dalam menilai hubungan biaya-manfaat tersebut (Mulyadi, 2008).

\section{Kas}

\subsection{Pengertian Kas}

Kas (cash) menurut Warren et al. (2010) meliputi uang receh, uang kertas, cek, wesel (money order) atau kiriman uang melalui pos yang lazim berbentuk draft bank atau cek bank; hal ini untuk selanjutnya diistilahkan dengan wesel, dan uang yang disimpan di bank yang dapat ditarik tanpa pembatasan dari bank bersangkutan.

\subsection{Fungsi Kas}

Fungsi kas menurut Kieso et al. (2008) menjelaskan sebagai berikut: "Kas, aset yang paling likuid adalah media standar pertukaran dan dasar untuk mengukur dan akuntansi untuk semua item lain."

\section{Sistem Pengendalian Intern Penerimaan Kas 10.1 Sistem A kuntansi Penerimaan Kas}


Sistem akuntansi penerimaan kas digunakan dalam perusahaan untuk menjalankan kegiatan operasional yang diperlukan oleh perusahaan. Berdasarkan sistem pengendalian intern yang baik, sistem penerimaan kas dari pendapatan mengharuskan :

1. Penerimaan kas dalam bentuk tunai harus segera disetor ke bank dalam jumlah penuh dengan cara melibatkan pihak lain selain kasir untuk melakukam internal check.

2. Penerimaan kas dari pendapatan tunai dilakukan melalui transaksi kartu kredit, yang melibatkan bank penerbit kartu kredit dalam pencatatan penerimaan kas.

\subsection{Ciri Pengendalian Intern Penerimaan Kas}

1. Berikut ini beberapa ciri pengendalian intern yang baik atas transaksi penerimaan kas: (1) Adanya pemisahan tugas dan tanggung jawab yang menerima kas dengan yang melakukan pencatatan, memberikan otorisas atas penerimaan kas.(2). Pegawai yang membat rekonsiliasi bank harus lain dari pegawai yang mengerjakan buku bank. Rekonsiliasi bank di buat setiap bulan dan harus ditelaah (direview) oleh kepala bagian akuntansi.(3). Penerimaan kas dalam bentuk apapun harus disetor ke bank dalam jumlah seutuhnya paling lambat keesokan harinya.(4)Uang kas harus disimpan ditempat yang aman.(5) Uang kas

\section{METODE PENELITIAN}

Objek penelitian ini adalah evaluasi sistem pengendalian intern penerimaan kas pada PDAM Tirta Anoa Kota Kendari yang beralamat di Jln. R. Suprapto No 90, Kendari, Sulawesi Tenggara. Jenis data yang digunakan dalam penelitian ini adalah data kualitatif yaitu data berupa penjelasan atau pernyataan yang tidak berbentuk angka-angka, seperti gambaran umum PDAM Tirta Anoa Kota Kendari.

\section{Teknik Pengumpulan Data}

Teknik yang digunakan dalam pengumpulan data adalah :

1. Wawancara yakni peneliti melakukan wawancara secara langsung terhadap fungsi-fungsi yang terkait mengenai pengendalian terhadap penerimaan kas.

2. Dokumentasi yakni peneliti akan mengumpulkan dokumen-dokumen terkait atas kas. Dokumen tersebut meliputi formulir-formulir yang digunakan dalam pengendalian internal penerimaan kas.

\section{Metode Analisis Data}

Metode analisis yang penulis gunakan adalah deskriptif. Di mana penelitian deskriptif adalah memberikan gambaran dan fakta kepada pembaca atas data-data yang diperoleh dari perusahaan kemudian data-data tersebut diolah menjadi informasi. Dari informasi tersebut dianalisis sehingga menjadikan kesimpulan (Sekaran, 2006).

\section{Definisi Operasional}

1. Pengendalian intern juga merupakan rencana organisasi dan metode bisnis yang dipergunakan untuk menjaga aset, memberikan informasi yang akurat dan andal, mendorong dan memperbaiki efisiensi jalannya organisasi, serta mendorong kesesuaian dengan kebijakan yang telah ditetapkan.

2. Kas adalah aktiva perusahaan yang berbentuk uang tunai (uang kertas, uang logam, wesel, cek, dan lainnya ) yang dipegang oleh perusahaan tersebut ataupun disimpan di bank dan dapat digunakan untuk kegiatan umum perusahaan.

3. Penerimaan kas adalah kas yang diterima oleh perusahaan dari pendapatana uang tunai maupun surat - surat berharga yang sifatnya dapat segera digunakan, dan berasal dari transaksi perusahaan maupun penjualan tunai, pelunasan piutang atau transaksi lainnya yang dapat menambah kas perusahaan. 


\section{HASIL PENELITIAN DAN PEMBAHASAN}

\section{Sistem Pengendalian Intern Penerimaan Kas dari Pembayaran Rekening Air Minum pada PDAM Tirta Anoa Kota Kendari}

1. Fungsi yang terkait dalam sistem penerimaan kas dari pembayaran rekening air pelanggan. Tugas urusan kas:

a. Membuat rencana kerja dan laporan kerja (bulanan dan tahunan) urusan kas.

b. Menerima pembayaran rekening air minum pelanggan dan menyetorkan kepada kas umum.

c. Membuat laporan penerimaan dan pengeluaran kas.

2. Dokumen

a) Rekening

Dokumen ini dihasilkan oleh bagian pembukuan dengan cara mengoperasikan komputer. Rekening ini merupakan bukti pembayaran rekening oleh pelanggan yang telah dicap "Lunas" oleh bagian kasir.

b) Pita register kas

Dokumen ini dihasilkan oleh bagian kasir dengan cara mengoperasikan mesin register kas. Pita register kas ini merupakan bukti pembayaran rekening yang dikeluarkan oleh bagian kasir.

c) Tanda Bukti Setor

Dokumen ini dibuat oleh bagian kepala urusan kas sebagai tanda bukti setor uang ke kas umum.

d) Buku Pengeluaran Rekening (BPR)

Dokumen ini digunakan untuk mencatat nomor kas, nominal, bulan rekening, dan tanggal pembayaran yang tercantum pada lembar rekening yang telah dibayar oleh pelanggan.

e) Laporan Penagihan Penagih (LPP)

Dokumen ini digunakan mencatat nomor kas, nama pelanggan, tanggal pembayaran rekening, dan rincian tagihan rekening air yang dibuat oleh bagian pembukuan.

f) Laporan Harian Penerimaan Kas (LHK)

Dokumen ini digunakan untuk mencatat nominal penerimaan kas pada hari tersebut.

g) Daftar Saldo Piutang Langganan (DSPL)

Dokumen ini digunakan untuk mencatat rincian nominal penerimaan kas yang dibuat pada akhir bulan.

3. Catatan Akuntansi

4. Prosedur Pembayaran Rekening

Evaluasi Sistem Pengendalian Intern Penerimaan Kas dari Pembayaran Rekening Air Minum pada PDAM Tirta Anoa Kota Kendari

Elemen Pokok Sistem Pengendalian Intern Pembayaran Rekening adalah sebagai berikut ini.

A. Struktur Organisasi

1) Fungsi kasir terpisah dari fungsi pembukuan. Fungsi kasir bertugas menerima pembayaran rekeneing dari pelanggan dan fungsi pembukuan bertugas mencetak rekening baru dan membuat laporan hasil pembayaran rekening.

2) Transaksi penerimaan kas dari pembayaran rekening oleh pelanggan tidak hanya melibatkan bagian kasir saja, akan tetapi melibatkan bagian lain. Prosedur pembayaran rekening air oleh pelanggan melibatkan empat bagian, yaitu:

1) Penerimaan Rekening 
Bertugas menerima contoh rekening air minum dari pelanggan dan mengurutkan serta menyimpan sementara rekening lembar kedua yang telah dibayar oleh pelanggan dan sudah dicap lunas oleh bagian kasir serta telah dicatat dalam Buku Pengeluaran Rekening oleh bagian pencatat pengeluaran rekening.

2) Pembukuan

Bertugas mencetak rekening air minum, Laporan Harian Penerimaan Kas (LHK), Laporan Penagihan Penagih (LPP), dan Daftar Saldo Piutang Langganan (DSPL) serta membuat jurnal penerimaan kas.

3) Kasir

Bertugas menerima pembayaran rekening air minum pelanggan, menyerahkan rekening air minum lembar ke-1 yang telah dicap "Lunas" dan pita register kas kepada pelanggan, serta menyerahkan rekening lembar ke-2 kepada bagian pencatat pengeluaran rekening.

4) Pencatat Pengeluaran Rekening

Bertugas menerima rekening lembar ke-2 dari bagian kasir dan mencatatnya ke dalam Buku Pengeluaran Rekening (BPR).

B. Sistem Wewenang dan Prosedur Pencatatan

1) Rekening yang akan dibayar oleh pelanggan diotorisasi terlebih dahulu oleh bagian kasir dengan dicap "Lunas".

Rekening air dihasilkan oleh Sub Bagian Rekening yang akan diberikan oleh fungsi kas yang digunakan untuk bukti pembayarann tagihan rekening air oleh pelanggan. Rekening air merupakan bukti pembayaran lunas atas tagihan rekening air oleh pelanggan setelah dicap "LUNAS" oleh fungsi kas.

2) Pencacatan transaksi pada jurnal penerimaan kas dilakukan oleh bagian pembukuan berdasarkan bukti kas masuk yang telah diotorisasi oleh bagian kasir dan bagian pencatat pengeluaran rekening.

C. Praktek yang Sehat dalam Melaksanakan Tugas dan Fungsi

a. Pada akhir hari dilakukan pencocokan antara jumlah fisik kas dengan jumlah kas yang ada pada catatan oleh bagian kasir, pembukuan, dan pencatat pengeluaran rekening.

b. Diadakan pemeriksaan secara mendadak terhadap jumlah uang yang diterima pada saat itu.

c. Diadakan rotasi jabatan.

D. Karyawan yang Mutunya sesuai dengan Tanggung Jawab

Karyawan PDAM Tirta Anoa Kota Kendari mempunyai latar belakang yang sesuai dengan pekerjaan mereka masing-masing dan melalui perekrutan karyawan yang sesuai dengan perkembangan sumber daya manusia.

\section{KESIMPULAN DAN SARAN}

\section{Kesimpulan}

Dalam penelitian ini dapat disimpulkan bahwa dalam pelaksaan penerimaan pembayaran rekening air minum PDAM Tirta Anoa Kota Kendari sudah menerpakan Sistem Pengendalian Intern yang cukup memadai. Hal ini dilihat dari terpenuhinya sebagian besar unsure sismtem pengendalian intern.

Namun untuk unsur sistem pengendalian intenr pada penerimaan kas yang berupa sistem otorisasi dan prosedur pencatatan belum sepenuhnya diterapkan karena otorisasi oleh pejabat yang berwenang dan bagian kasir dalam satu hari bisa dipegang oleh beberapa bagian. 


\section{Saran}

Berdasarkan uraian yang telah penulis paparkan di atas, maka perlu diadakan koreksi terhadap SPI pada sistem penerimaan kas dari pembayaran rekening air minum oleh pelanggan. Hal ini untuk melindungi harta kekayaan perusahaan dari pencurian, penggelapan, atau persekongkolan antara karyawan dengan pihak ketiga, antara lain sebagai berikut ini:

1. Dalam prosedur penerimaan kas dari pembayaran rekening air minum pelanggan PDAM Tirta Anoa Kota Kendari dalam satu hari bagian kasir tidak boleh dilakukan oleh empat bagian. Karena sistem pengendalian intern yang baik harus ada pemisahan fungsi secara tegas antara bagian pelaksanaan, penyimpanan, dan pencatatan.

2. Pengarsipan terhadap dokumen-dokumen lebih dijaga dan dirawat, supaya terhindar dari kehilangan data.

3. Pada saat listrik padam sebaiknya mengunakan generator listrik agar sistem penerimaan kas tetap berlangsung.

4. Untuk pelanggan yang menunggak pembayarn sebaiknya diberi sanksi tegas.

\section{DAFTAR PUSTAKA}

Agoes, Sukrisno. 2012. Auditing: Petunjuk Praktis Pemeriksaan Akuntan oleh Akuntan Publik. Edisi Keempat. Jakarta: Salemba Empat.

Arens, Alvin A., Randal J. Elder, Marks S. Basley. 2013. Jasa Audit dan Assurance. Diterjemahkan oleh Amir Abadi Jusuf. Jakarta: Salemba Empat.

Arnas, Aulia, Yunus Tete Konde, Muhammad Ikbal. 2010. Analisis Penerapan Pengendalian Intern Kas pada PT. Kaltim Nusa Etika (KNE) di Bontang.

Arnas. 2010. Analisis Penerapan Pengendalian Intern Kas pada PT Kaltim Nusa Etika (KNE) di Bontang.

Baridwan, Zaki. 2014. Intermediate Accounting. Yogyakarta: BPFE Yogyakarta.

Bank Indonesia. 2014. Buku Pedoman Sistem Pengendalian Intern BPR. Surakarta.

Holmes, Arthur. W dan David C. Burns. 2010. Auditing Norma dan Prosedur. Diterjemahkan oleh Moh. Badjuri. Jakarta: Salemba Empat.

Handayaningrat, S. 2011. Pengantar Suatu Ilmu Administrasi Dan Manajemen. Jakarta: Gunung Agung.

Hidiar, Estiana Patri. 2012. Analisis Sistem Pengendalian Intern Penerimaan Kas Pendapatan Asli Daerah pada Dinas Pendapatan Pengelolaan Keuangan dan Asset Daerah Kabupaten Blitar. Universitas Brawijaya.

Kieso, Donald E.; Jerry J. Weygandt; Terry D. Warfield. 2014. Intermediate Accounting. Jakarta: Erlangga.

Kasmir,SE.,MM. 2011. Bank dan Lembaga Keuangan Lainnya. Edisi ke-6. Jakarta. Kelapa Gading Permai.

Kieso, Donald E., Jerry J. Weygant, dan Terry D. Warfield. 2010. Akuntansi Intermediate. Jakarta: Erlangga.

Mulyadi. 2011. Sistem Akuntansi. Yogyakarta: STIE YKPN.

Mulyadi. 2010. Sistem Akuntansi. Edisi ke-3. Jakarta . Salemba Empat.

Pardana, Mahardika. 2010. Evaluasi Sistem Pengendalian Intern Penerimaan dan Pengeluaran Kas Koperasi Pegawai Republik Indonesia (PRI) Universitas Malang. Universitas Brawijaya.

Pradipta, Rahmada Bana. 2010. Analisis Pengendalian Intern Atan Penerimaan dan Pengeluaran Kas pada PT Sari Ayu Indonesia cabang Malang. Universitas Brawijaya. 
Jurnal Akuntansi dan Keuangan Volume V/1/Februari 2020

ISSN (Online) : 2503-1635, ISSN (Print): 2088-4656

Parlin, Raykard. 2012. Analisis Sistem Pengendalian Internal Kas pada PT. Bank Nasional Indonesia (BNI).

Romney, Marshall B. dan Paul John Steinbart. 2012. Accounting Information Systems. Jakarta: Salemba Empat.

Suwardjono.2013. Akuntansi Pengantar. Yogyakarta: BPFE Yogyakarta.

Warren, Carls S, James M. Reeve dan Philip E. Fees. 2010. Pengantar Akuntansi. Jakarta: Salemba Empat. 